\title{
COMPRESSION AND TENSION CREEP BEHAVIOUR OF LVL SENGON (PARASERIANTHES FALCATARIA)
}

\author{
Achmad Basuki ${ }^{1,2}$, Ali Awaludin*3, Bambang Suhendro ${ }^{3}$, and Suprapto \\ Siswosukarto ${ }^{3}$ \\ ${ }^{1}$ Department of Civil and Environmental Engineering, Faculty of Engineering, Universitas Gadjah Mada, \\ Yogyakarta, Indonesia \\ ${ }^{2}$ Department of Civil Engineering, Faculty of Engineering, Universitas Sebelas Maret, Surakarta, Indonesia \\ ${ }^{3}$ Department of Civil and Environmental Engineering, Faculty of Engineering, Universitas Gadjah Mada, \\ Yogyakarta, Indonesia, Tel: +62-274-545675, e-mail: ali.awaludin@ugm.ac.id
}

Received Date: March 25, 2020; Revised Date: July 29, 2020; Acceptance Date: August 13, 2020

\begin{abstract}
This study was aimed to investigate the creep behavior of laminated veneer lumber (LVL) Sengon, especially under the application of compression and tension stress parallel-to-the-grain. In Indonesia LVL made from the fast-growing Sengon (Paraserianthes falcataria) species is designed to be used as a substitution for solid wood in building construction. Creep test was conducted on the specimens with reference to the ASTM D143-09 standard test methods for small clear specimens of timber. Moreover, the constant loads were made equal to about $20 \%, 30 \%$, and $40 \%$ of the $60 \%$ ultimate load derived from the static test and the creep test was conducted in a chamber having an average temperature of $25^{\circ} \mathrm{C}$ and minimum relative humidity of $65 \%$. The results of creep test for a period of 90 days showed that the creep factors were $0.51,0.52$, and 0.41 , respectively for the specimens under tension stress level of $20 \%, 30 \%$, and $40 \%$, respectively. In the case of specimen under compression stress parallel-to-the-grain, the creep factors were $0.42,0.41$, and 0.31 , respectively, for stress level equals to $20 \%, 30 \%$, and $40 \%$. It can be concluded that the creep factor under tension stress is slightly higher than that of specimens under compression stress, and these obtained creep factors are much lesser than the values provided in the code.
\end{abstract}

Keywords: Compression creep, Creep factors, LVL Sengon, Tension creep

\section{Introduction}

Laminated Veneer Lumber (LVL) Sengon is one of the innovative engineered wood products developed to fulfill the need for housing construction materials as sawn lumbers from natural forests are very limited recently. Moreover, these LVL products have better mechanical properties which make them more useful as building materials. Sengon trees are one of the fast-growing species widely planted in Southeast Asia, India, and Southern China with different local names such as Sengon, jeungjing (Indonesia), batai, machis (Malaysia), moluccan sau, falcata (Philippines), puah (Brunei), white albizia (Papua New Guinea), kool (Cambodia), Khang (Laos), khang hung (Thailand), and cham (Vietnam) [1]. In Indonesia, this tree has been widely cultivated by forest communities and harvested after a period of 46 years. However, sawn Sengon woods have been reported to have low mechanical properties as evident with the density of $260 \mathrm{~kg} / \mathrm{m}^{3}$ at a moisture content of $12 \%$ [2]. Therefore, its utilization is limited to non-structural components such as wallboards, formwork, and box packaging. 
In other countries, engineered wood products such as plywood, LVL, and parallel strand lumber (PSL) also generally involve veneers derived from low to medium density species between 290-690 kg/m ${ }^{3}$. In North America and Europe, Aspen (Populus tremuloides), Poplar (Populus balsmifera), Red Oak, Red Maple, and Birch made using different names such as SELECTEM, Microllam, Parallam are being used [3]. Meanwhile, in Asian countries, besides Sengon, wood species such as Acacia mangium, Gmelina arborea, Hevea brasiliensis, Tsugi and Eucalyptus deglupta are also used [4, 5].

There is a need for the development of LVL innovation from Sengon wood through the use of research related to its short-term and long-term behavior, utilization as well as on the efforts to improve its mechanical properties. Awaludin, et al. [6] reported the mechanical properties of this product are better compared to Sengon wood as observed with the $57 \%$, $33 \%, 33 \%$, and $92 \%$ increase in its density, modulus of elasticity (MoE), tensile, and compressive strength parallel to the grain, respectively. It also has good dimensional and geometry stability. Several methods to improve the mechanical properties of LVL has been suggested by previous studies such as: veneer resin impregnation [7]; veneer densification processes [8]; glass fiber fabric reinforcement [9]; addition of high density veneers such as Poplar, Eucalyptus, and their combination [10]; manufacturing coextruded composites with a core-shell structure where LVL as the core layer and wood-plastic composites as the shell layer [11].

Due to the numerous benefits attached to LVL Sengon, it is recently being used as a material for residential building structures and furniture components. Moreover, Awaludin et al. and Wusqo et al. have also utilized LVL Sengon as a shear wall, I-shaped beams, boxshaped beams, floor system, and roof truss and some of the studies conducted have shown promising results [6, 12]. Hadi et al. [13] have also researched the utilization of LVL Sengon and Rubber wood composite shear walls in earthquake-resistant houses. However, those experiments were conducted under static and dynamic load in a short-time duration, thus investigation for a long-term period to determine the product's structural performance during its service life is required.

Creep behavior influences the long-term performance of LVL Sengon construction as observed in the continuous increase in deformation when subjected to a constant load during its service life. This has caused several problems such as excessive deformation and strength loss, and consequently creep rupture and buckling. Several studies have been conducted on wood creep using structural and small sizes as well as different tests on bending creep $[14,15,16]$. The building codes as National Design Specification (NDS) for Wood Construction, Eurocode 5, New Zealand Standard 3603 provide strength reduction factors to take into account the tertiary phase of creep and multiplying the elastic deformation by a creep factor [17]. In order to calculate creep deformation, some codes containing timedependent deformation factor like creep has been designed, for example The National Design Specification (NDS) formulated to determine the total long-term deflection of the member $\left(\Delta_{T}\right)$ using the following equation:

$$
\Delta_{T}=K_{C R} \Delta_{L T}+\Delta_{S T}
$$

where $K_{C R}=$ creep factor, equals to 1.5 for laminated timber or seasoned lumber and 2.0 for unseasoned lumber, $\Delta_{L T}=$ immediate deflection due to the long-term component of design load, and $\Delta_{S T}=$ deflection due to the short-term or normal component of the design load [18]. This equation has also been adopted by the Indonesian National Standard (SNI) 7973:2013 Design Specification for Wood Construction [19]. 
equation [20]:

The creep factor of the experiment can also be calculated using the following

$$
k_{\text {creep }-t}=\left(\varepsilon_{t}-\varepsilon_{0}\right) / \varepsilon_{0}
$$

where $k_{\text {creep- } t}=$ creep factor at time $t, \varepsilon_{t}=$ strain at time $t$, and $\varepsilon_{0}=$ initial strain.

The objective of this study was to examine the long-term behavior of LVL Sengon under uniform compression and tension stresses parallel-to-the-grain. This includes determining the effect of load level on creep deformation, developing the Burger and Prony Series models to predict long-term deformation and comparing creep factor from the experiment to the design specification.

\section{Creep Models}

Wood and wood-based composite materials are generally modeled as a viscoelastic material, where the application of constant stress over a period of time leads to an increase in deformation after the initial elastic deformation. However, a simple model combining spring and dashpot elements can be used to describe this viscoelastic behavior.

The creep model was developed to predict both primary and secondary creep behavior. In this research, the Burger creep or the four-element viscoelastic model was used because it is the main material for wood or wood-based products [21, 22]. The Burger model consists of a spring in series with a dashpot combined with another in parallel with a dashpot as shown in Figure 1(a). For the uniaxial stress, the elastic constants, viscosity coefficients, stress, and strain are mathematically presented in Equation (3).

$$
\varepsilon(t)=\beta_{1}+\beta_{2}\left(1-e^{-\left(\beta_{3}\right) t}\right)+\beta_{4} t
$$

where $\beta_{1}=\frac{\sigma_{0}}{E_{1}}, \beta_{2}=\frac{\sigma_{0}}{E_{2}}, \beta_{3}=\frac{1}{\tau}, \beta_{4}=\frac{\sigma_{0}}{\eta_{2}} . \sigma_{0}$ represents the initial stress, $E_{1}$ and $E_{2}$ are the instantaneous and delayed elastic modulus, $\eta_{2}$ is the viscosity coefficient for permanent strain, and $\tau=\eta_{1} / E_{2}[20]$.

Another model used for curve fitting of creep test data is the Prony series, which also consists of spring and dashpot models arranged as shown in Figure 1.b. This model is provided in ABAQUS software and has been found to be effective for modeling long-term creep testing [23] with a number $n$ of decaying exponentials as shown in Equation (4).

$$
D(t)=E_{\infty}+\sum_{i=1}^{n} E_{i} \exp \left(-t / \tau_{i}\right)
$$

where $\tau_{i}$ are the relaxation times, $E_{i}$ are the relaxation moduli, and $E_{\infty}$ is the equilibrium modulus. The Prony series model can also be written in terms of shear modulus as presented in Equation (5).

$$
G(t)=G_{0}\left(1-\sum_{i=1}^{n} g_{i}\right)+\sum_{i=1}^{n} g_{i} G_{0} \exp \left(-t / \tau_{i}\right)
$$

where $g_{i}=G_{i} / G_{0}, G_{0}$ is the initial value of shear modulus obtainable from Equation (6). 


$$
G_{0}=\frac{E_{0}}{2(1+v)}
$$

where $E_{0}$ is the initial value of elastic modulus and $v$ is the Poisson ratio.

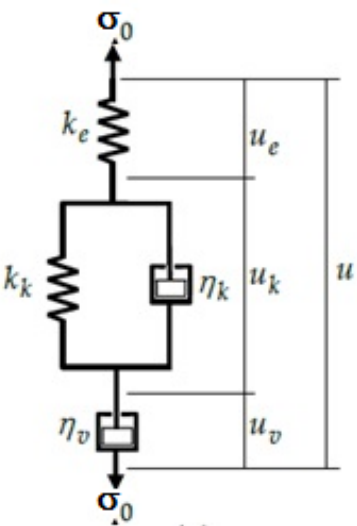

(a)

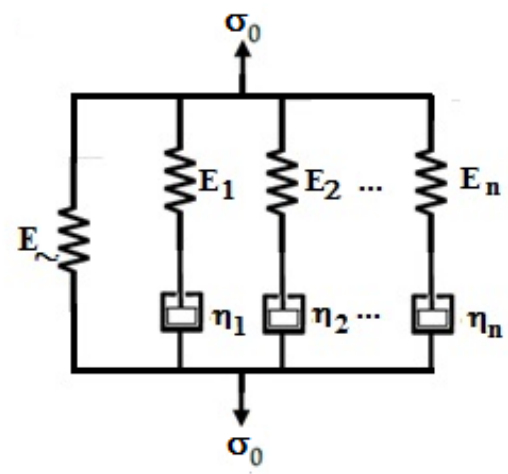

(b)

Figure 1. Creep model: (a) Burger model and (b) Prony series model

The parameters $\beta_{1}, \beta_{2}, \beta_{3}$, and $\beta_{4}$ of the Burger model and the parameters $g_{i}$ and $\tau_{i}$ of the Prony Series model as written in Equation (3) and (5), respectively, can be calculated by the iteration process using the SOLVER program which is available in the Microsoft Excel program [24, 25]. The subscript $i$ shows the number of spring and dashpot series (Maxwell) used in the Prony series model. In this study, two Maxwell series $(i=2)$ were used.

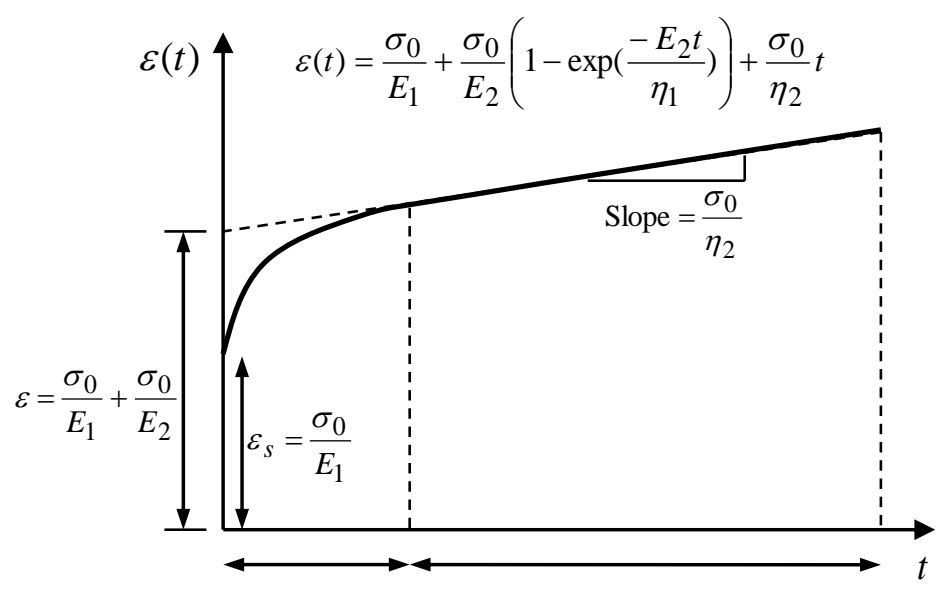

Figure 2. Creep response of the Burger model

The limit of the two creep stages, primary and secondary, can be determined graphically using the equation of the Burger model as in Figure 2, where there is no occurrence of the tertiary stage. The limit is represented by the linear line obtained from the sum of the initial and delayed elastic stretches, with the slope determined by the viscoelastic strain. The starting point for the creep curve meeting with this linear line is the time limit for the primary and secondary creep stages. 


\section{Material and Method}

The LVL Sengon used was manufactured using veneers with a thickness of 2.2-3.2 mm as shown in Figure 3. The veneers were selected by ensuring they are free of wood defects (knots) and dried until they reached a maximum water content of $12 \%$. In order to fulfill the required length, the edges of the veneers were jointed and heat-compressed with a plain scarf joint model. Furthermore, melamine-urea formaldehyde (MF) adhesive was sprayed on the surface evenly and laminated together in the same direction or parallelto-the-grain according to the LVL thickness requirement, for example, if a $40 \mathrm{~mm} \mathrm{LVL}$ thickness was to be produced, 20 plies of $2.2 \mathrm{~mm}$ veneers would be laminated with the layers pressed with pressure from 0.6 to $0.7 \mathrm{MPa}$ at $105^{\circ} \mathrm{C}-110^{\circ} \mathrm{C}$ for 1 hour. This would be followed by the sanding process to smoothing the surface and achieve the required thickness. Finally, the LVL would be cut according to the expected size. The LVL Sengon used as specimens have an average moisture content of $14.3 \%$ (minimum $13.3 \%$, maximum $15.6 \%$ ) and an average density of $0.344 \mathrm{gr} / \mathrm{cm}^{3}$ (minimum $0.332 \mathrm{gr} / \mathrm{cm}^{3}$, maximum $0.358 \mathrm{gr} / \mathrm{cm}^{3}$ ).
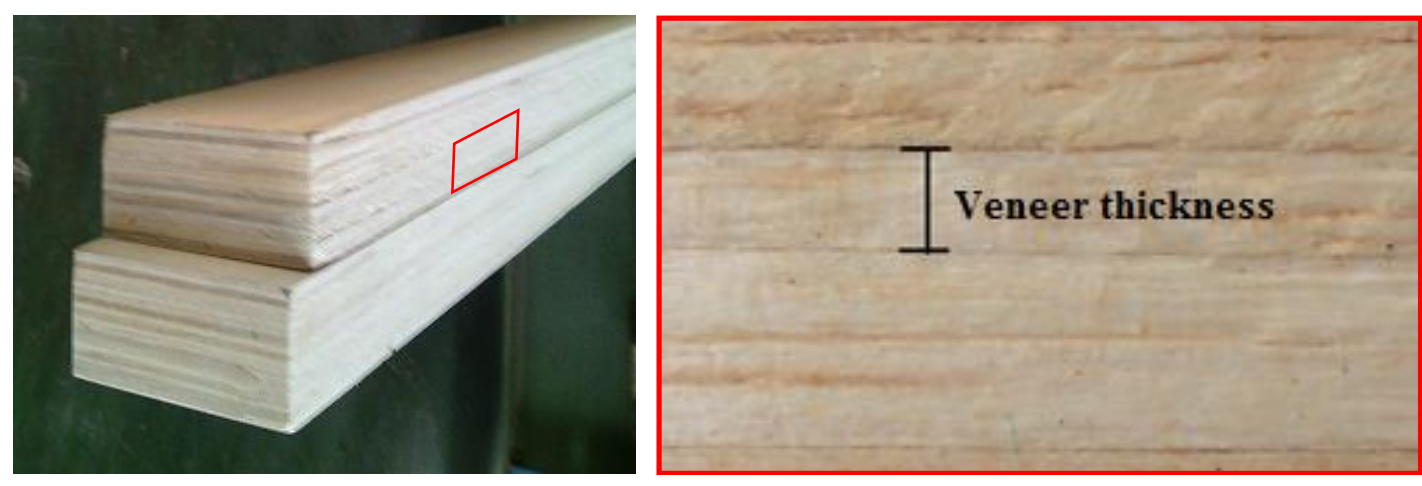

Figure 3. LVL Sengon

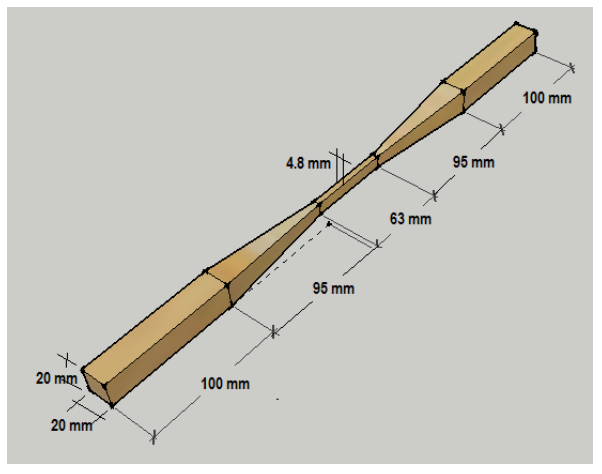

(a)

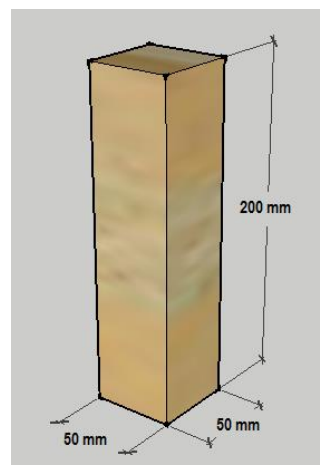

(b)

Figure 4. Specimen geometry of (a) tension and (b) compression (ASTM D143-09)

\section{Tension and Compression Properties Test}

Three groups of specimens were tested and they include those related to the mechanical properties, creep under a compression load, and creep under tension load. ASTM D14309 Standard Test Methods for Small Clear Specimens of Timber [26] was used in group test number 1. Moreover, the specimens used for the compression test have the same dimensions of $50 \mathrm{~mm}$ width, $50 \mathrm{~mm}$ thickness, and $200 \mathrm{~mm}$ length as shown in Figure 3 and capped with gypsum to obtain a flat surface to ensure uniform load distribution 
during the test. However, for the tension test, a $10 \mathrm{~mm}$ x $4.8 \mathrm{~mm}$ x $63 \mathrm{~mm}$ dimension was used as shown in Figure 4. Both the tensile and compressive tests were conducted on the Universal Testing Machine (UTM) apparatus with a loading rate of $1 \mathrm{~mm} / \mathrm{min}$.

\section{Compression and Tension Creep Test}

Special apparatuses designed for one stress level were used for the compression and tension creep tests using three specimens arranged in series as shown in Figures 5 and 6, respectively. This load system was calibrated using a load cell and the applied load in compression and tension specimens was found as 5.6 and 3.4 times of the block weight. The lever arms were designed to be stiff enough to avoid possible torsional deformation.
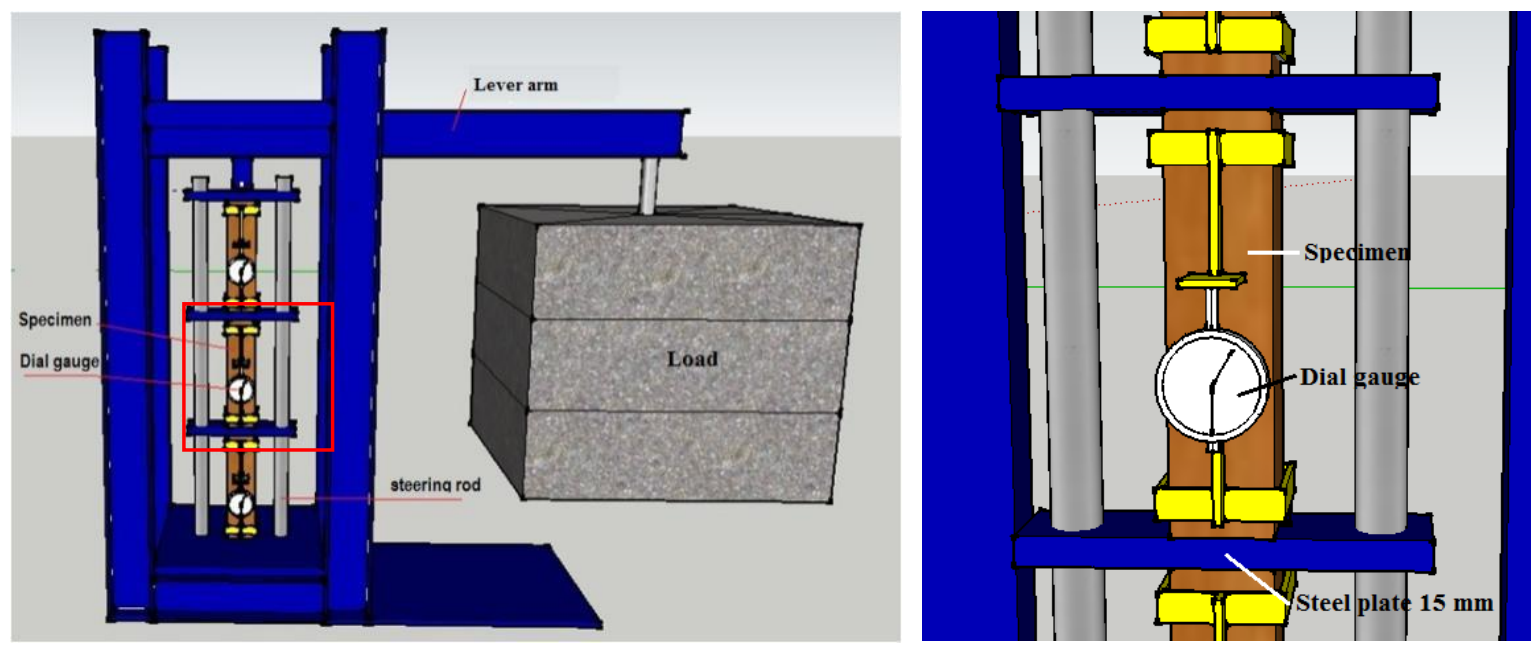

Figure 5. Set up for the compressive creep test
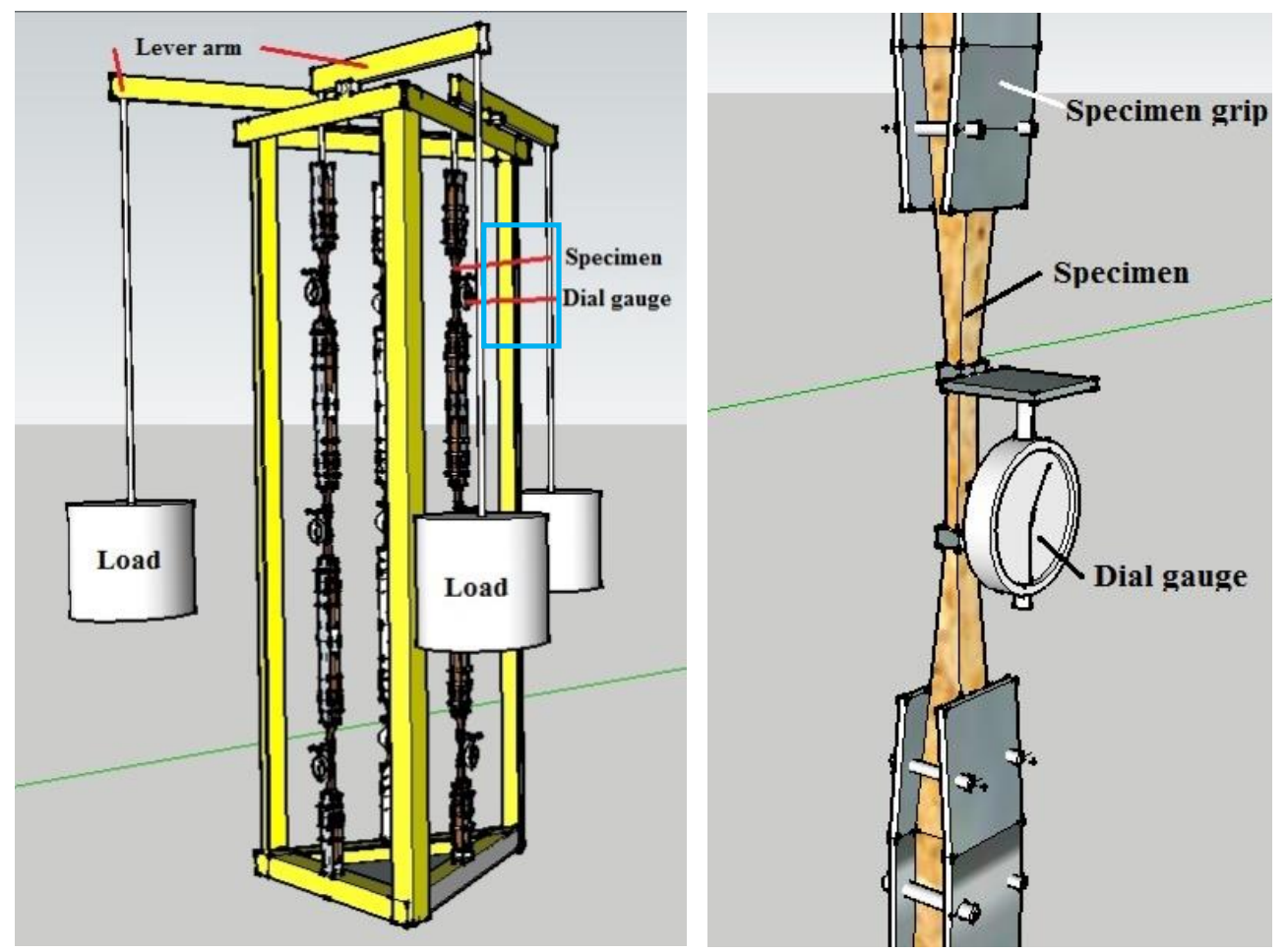

Figure 6. Set up for the tensile creep test 
The creep tests were conducted in a chamber equipped with an air conditioner and humidifier. However, it was not a special room for creep testing where usually the temperature and RH are being controlled actively but made available in the laboratory for long period observation experiments such as the creep test. The windows were covered with thick black papers to refrain sunlight entering while the air ventilation holes were closed to ensure the effectiveness of the air conditioner and humidifier. The temperature and relative humidity were determined based on the measurements recorded over the last 9 months in the Structural Engineering Laboratory of Universitas Gadjah Mada, Yogyakarta and the minimum, maximum, and average temperature were found to be $23.1^{\circ} \mathrm{C}, 29^{\circ} \mathrm{C}$, and $25.8^{\circ} \mathrm{C}$, respectively. The relative humidity was fluctuated from $47 \%$ to $99 \%$ while the average was $83.9 \%$. A similar case found in Niken et al. [27] with the chamber to test concrete shrinkage conditioned to have a temperature $28 \pm 3^{\circ} \mathrm{C}$ and relative humidity $72 \pm 5 \%$ at Universitas Indonesia, Jakarta.

The temperature and relative humidity $(\mathrm{RH})$ were adjusted using a hygrothermostat, air conditioner, and humidifier. The air conditioner was set at $25^{\circ} \mathrm{C}$ while the minimum RH was set at $65 \%$ using a hygro-thermostat. These factors were further recorded every 10 minutes using a hygro-thermostat recorder RS-12 Espec. Each load level of compressive and tensile creep tests consisted of three specimens to have a total of nine specimens each for both. The elastic deformation was measured after 1 minute of loading a specimen while the deformation data was recorded with a short duration on the first day of testing to obtain an adequate change in creep rate.

\section{Results and Discussion}

\section{Compressive and Tensile Test of LVL Sengon}

The short-term test was conducted to obtain the basic mechanical properties such as modulus of elasticity $(\mathrm{MoE})$, maximum tension and compression strength and this was conducted using 5 and 6 specimens for compression and tension, respectively with reference to ASTM D143-09 Standard Test Methods for Small Clear Specimens of Timber

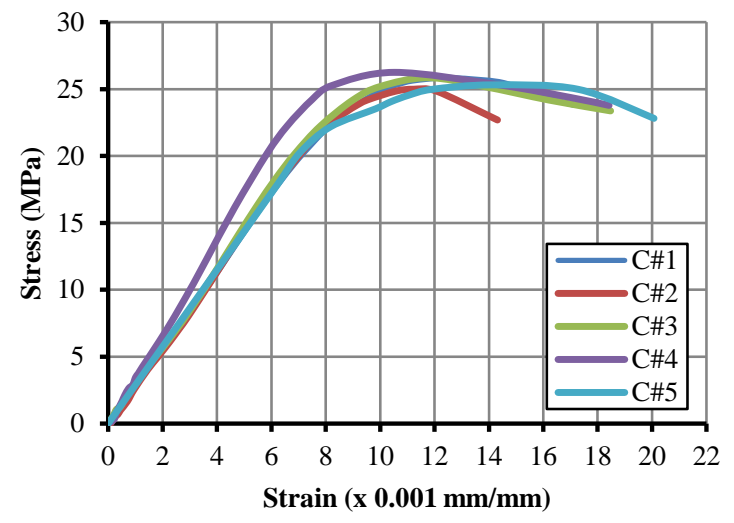

(a)

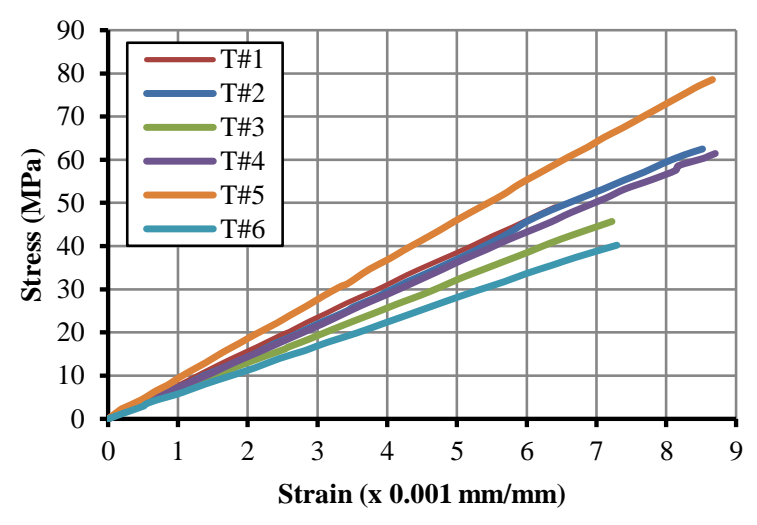

(b)

Figure 7. The result of (a) compressive and (b) tensile tests

Figure 7 shows the average compressive strength was $25.6 \mathrm{MPa}$, and the $\mathrm{MoE}$ in compression was $2898 \mathrm{MPa}$ while the average tensile strength was $53.0 \mathrm{MPa}$ and the MoE in tension was $7256 \mathrm{MPa}$. These results were not too different from the findings of Eratodi et al. [28] which recorded MoE in compression and tension to be $2253 \mathrm{MPa}$ and $7083 \mathrm{MPa}$, respectively. These results for the compression presented in Table 1 and tension in Table and were further used as the reference to determine the load level of the compression and tension creep tests. 
Table 1. Results of LVL Sengon Compression Test

\begin{tabular}{ccccc}
\hline Code & $\begin{array}{c}\text { Max. Load } \\
(\mathbf{N})\end{array}$ & $\begin{array}{c}\text { Max. Strain } \\
(\mathbf{m m} / \mathbf{m m})\end{array}$ & $\begin{array}{c}\text { Max. Stress } \\
(\mathbf{M P a})\end{array}$ & $\begin{array}{c}\text { Modulus of } \\
\left.\text { Elasticity, } \boldsymbol{E}_{\boldsymbol{c}}, \mathbf{( M P a}\right)\end{array}$ \\
\hline C\#1 & 65230 & 0.01238 & 25.85 & 2686 \\
$\mathrm{C \#} 2$ & 62301 & 0.01124 & 24.98 & 2834 \\
$\mathrm{C \# 3}$ & 64120 & 0.01175 & 25.84 & 2807 \\
C\#4 & 65100 & 0.01052 & 26.24 & 3291 \\
C\#5 & 62780 & 0.01413 & 25.31 & 2869 \\
\hline Average & 63906 & 0.01200 & 25.64 & 2898 \\
\hline
\end{tabular}

Table 2. Results of LVL Sengon Tension Test

\begin{tabular}{ccccc}
\hline Code & $\begin{array}{c}\text { Max. Load } \\
(\mathbf{N})\end{array}$ & $\begin{array}{c}\text { Max. Strain } \\
(\mathbf{m m} / \mathbf{m m})\end{array}$ & $\begin{array}{c}\text { Max. Stress } \\
(\mathbf{M P a})\end{array}$ & $\begin{array}{c}\text { Modulus of } \\
\text { Elasticity, } \boldsymbol{E}_{\boldsymbol{t}}, \mathbf{( M P a )}\end{array}$ \\
\hline T\#1 & 2210 & 0.00641 & 49.11 & 8070 \\
T\#2 & 3170 & 0.00852 & 43.36 & 7334 \\
T\#3 & 2260 & 0.00722 & 45.70 & 6258 \\
T\#4 & 2830 & 0.00870 & 61.44 & 7387 \\
T\#-5 & 3620 & 0.00866 & 78.55 & 9148 \\
T\#6 & 2040 & 0.00729 & 40.21 & 5336 \\
\hline Average & 2688 & 0.00780 & 53.06 & 7256 \\
\hline
\end{tabular}

The load level for the creep test was determined based on the elastic condition from the short-term test which was set at $60 \%$ of the average maximum load. The applied load level for both compression and tension creep test were around $20 \%, 30 \%$, and $40 \%$ of the elastic condition. Actual load for the specimens under compression stress, however, were $8630 \mathrm{~N}$ (or $22 \%$ ), $12875 \mathrm{~N}$ (or 33\%), and $17775 \mathrm{~N}$ (or 46\%), while for those specimens tested under tension stress were $283 \mathrm{~N}(17.5 \%), 425 \mathrm{~N}$ or $(26.3 \%)$, and $566 \mathrm{~N}(35 \%)$. This was solely due to limitation of weight block available in the laboratory.

\section{Temperature and RH Measurement}

The data recorded in the creep test room showed the average temperature was $25.18^{\circ} \mathrm{C}$ with a minimum and maximum of $22.3^{\circ} \mathrm{C}$ and $26.3^{\circ} \mathrm{C}$ respectively while the average $\mathrm{RH}$ was found to be $80.98 \%$ with a minimum and maximum of $65 \%$ and $89 \%$ as shown in Figure 8 . This shows the room was being influenced by the environmental condition. However, the fluctuation of the RH distribution within the observation period was within the expected range.

\section{Creep Test of LVL Sengon}

The results of the compression and tension creep test for 90 days were shown in Figures 9 and 10 respectively. These graphs show the relationship between time (days) and deformation $(\mathrm{mm})$ and a typical creep curve was observed with a fast increment in the early stage and stability at the next stage. For each stress level, the instantaneous deformation of specimens was proportional but had no same value due to the difference in the modulus of elasticity of LVL Sengon. Therefore, the initial deformation value was normalized to obtain the same values for the three specimens at each loading level by referring to the average modulus of elasticity $(E)$ and the stress applied. Furthermore, the next deformation data were adjusted by multiplying the initial deformation ratio of the test results with the initial deformation based on the average value of $E$. 


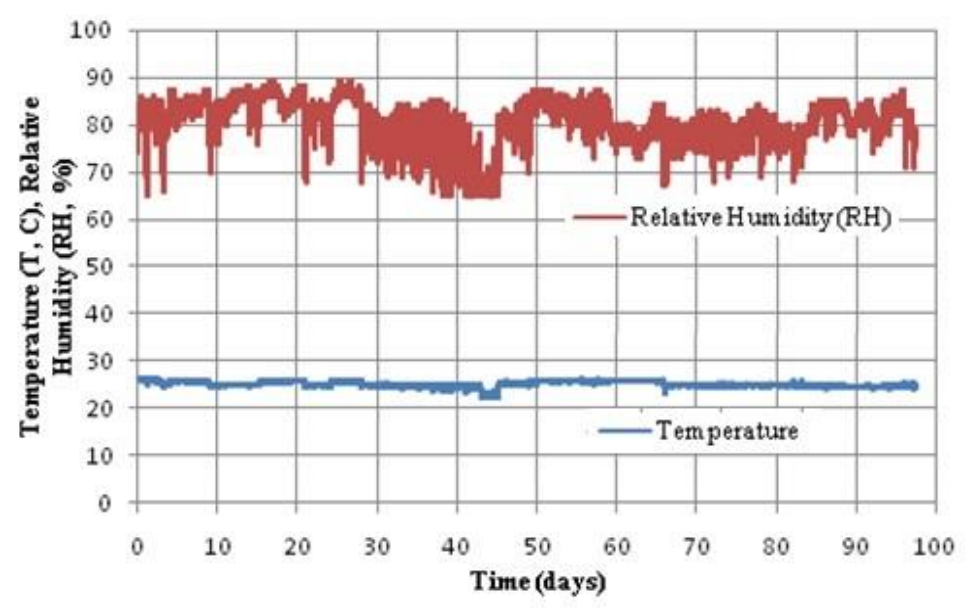

Figure 8 . Temperature and relative humidity during the creep testing

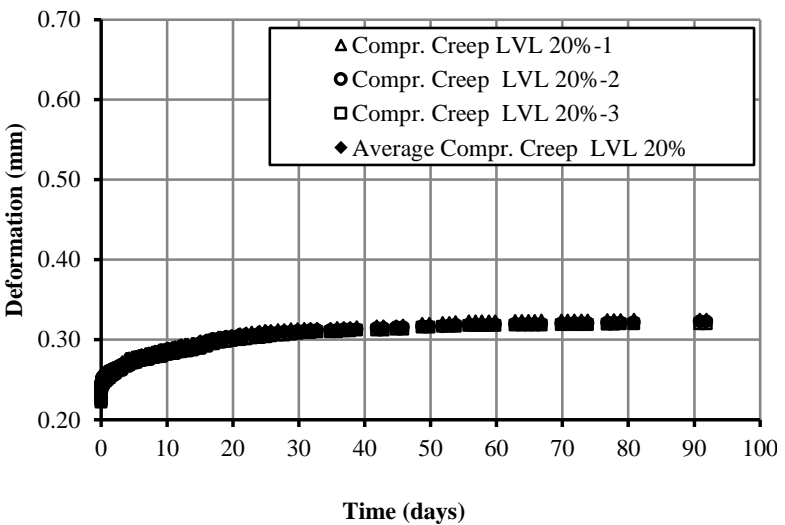

(a)

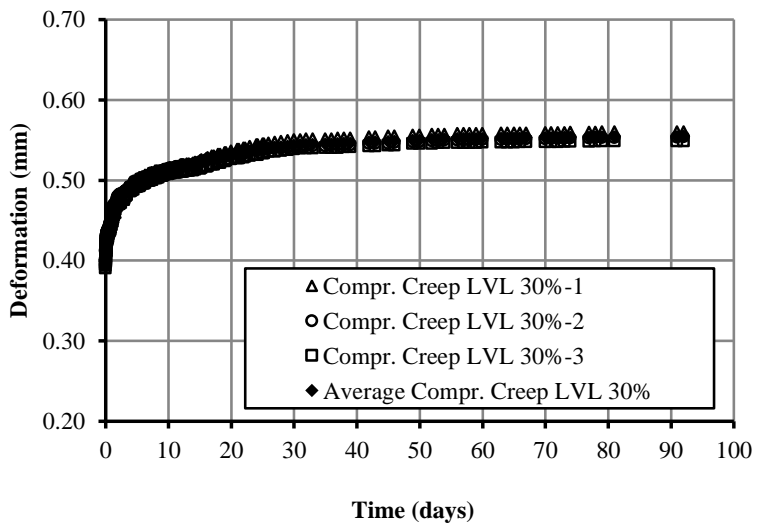

(b)

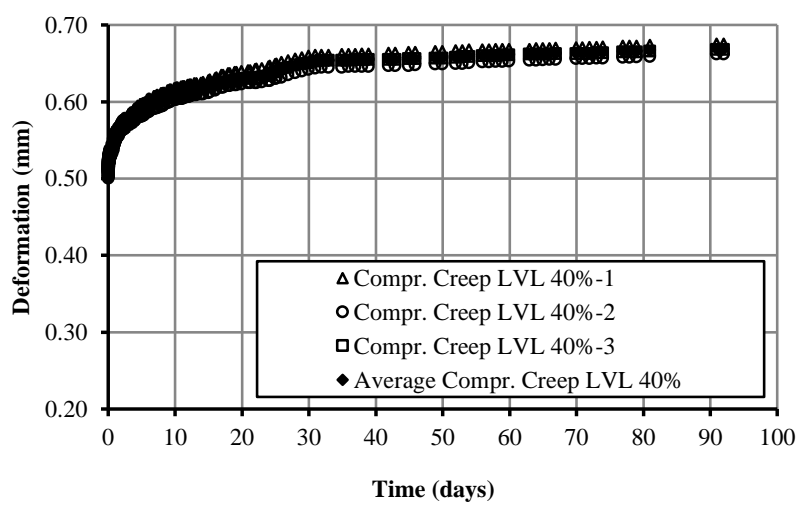

(c)

Figure 9. Compression creep test at (a) $20 \%$ (b) $30 \%$, and (c) $40 \%$ load levels

The initial value of shear modulus $\left(G_{0}\right)$ in Equation (4) was calculated using Equation (5) where the initial elastic modulus $\left(E_{0}\right)$ was $E_{\mathrm{c}}=2898 \mathrm{MPa}$ and $E_{\mathrm{t}}=7256 \mathrm{MPa}$ for compression and tension, respectively. The Poisson ratio $(v)=0.225$ was obtained from the LVL Sengon test conducted by Eratodi and Awaludin [28]. Meanwhile, the results of the 
iteration of parameters $\beta_{1}, \beta_{2}, \beta_{3}$, and $\beta_{4}$ in the Burger model and $g_{\mathrm{i}}$ and $\tau_{1}$ of the Prony series $(i=2)$ model are presented in Tables 3 and $4 . g_{\mathrm{i}}$ and $\tau_{i}$ were required as input data to simulate the viscoelastic material properties of LVL Sengon members in ABAQUS software.

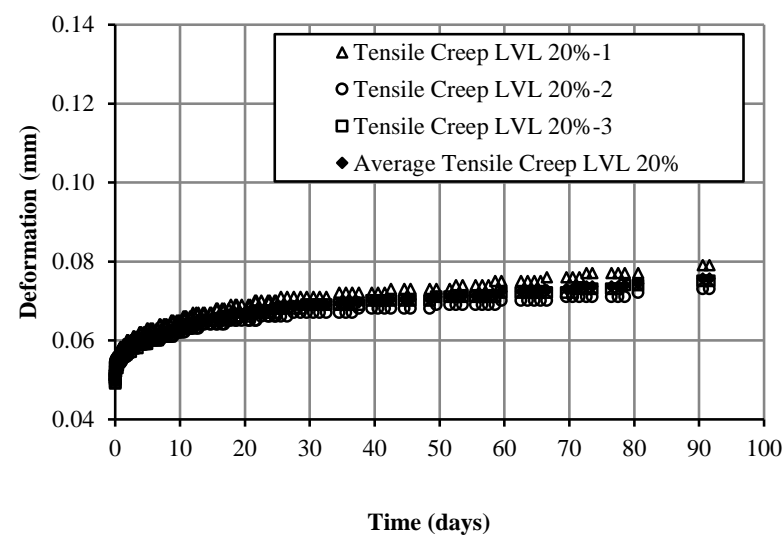

(a)

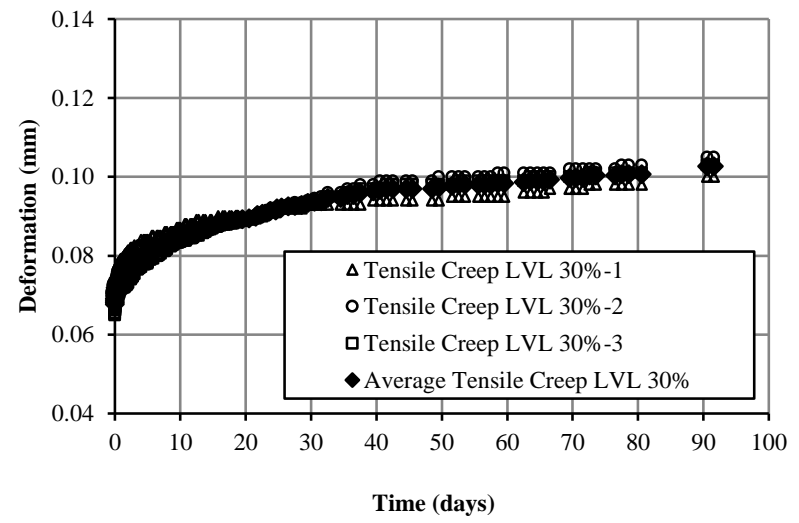

(b)

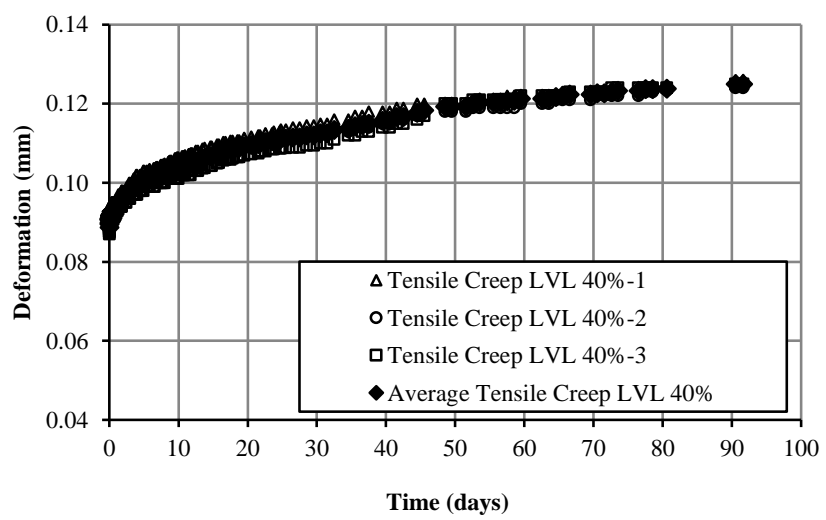

(c)

Figure 10. The tension creep test at (a) 20\%, (b) $30 \%$, and (c) $40 \%$ load levels

Table 3. Parameters of Burger Model of Compression and Tension Creep Test and Creep Factor for 90 days

\begin{tabular}{cccccccc}
\hline & $\begin{array}{c}\text { Load } \\
\text { Level }\end{array}$ & $\boldsymbol{\beta}_{1}$ & $\boldsymbol{\beta}_{\mathbf{2}}$ & $\boldsymbol{\beta}_{\mathbf{3}}$ & $\boldsymbol{\beta}_{4}$ & $\mathbf{R}^{\mathbf{2}}$ & $\boldsymbol{k}_{\text {creep-90 }}$ \\
\hline Compression & $20 \%$ & 0.00119 & 0.00047 & 0.11362 & 0.0000002 & 0.87 & 0.41 \\
Creep Test & $30 \%$ & 0.00177 & 0.00071 & 0.16183 & 0.000001 & 0.82 & 0.41 \\
& $40 \%$ & 0.00245 & 0.00062 & 0.16182 & 0.000001 & 0.98 & 0.32 \\
\hline Tension & $20 \%$ & 0.00090 & 0.00032 & 0.07315 & 0.000002 & 0.94 & 0.39 \\
Creep Test & $30 \%$ & 0.00128 & 0.00040 & 0.16279 & 0.000003 & 0.95 & 0.53 \\
& $40 \%$ & 0.00171 & 0.00033 & 0.16279 & 0.000004 & 0.98 & 0.44 \\
\hline
\end{tabular}


Due to the very small rate of desorption and absorption in large specimens, the effect on changes in water content in the wood cell walls was also very small. The analysis of creep curve development showed both compression and tension test data were not significantly influenced temperature and relative humidity.

Table 4. Parameters of Prony Series, $E$, and $G$ of Compression and Tension Creep Test Creep Factor for 90 days

\begin{tabular}{ccccccccc}
\hline & $\begin{array}{c}\text { Load } \\
\text { Level }\end{array}$ & $\begin{array}{c}\boldsymbol{E}_{\mathbf{0}} \\
(\mathbf{M P a})\end{array}$ & $\begin{array}{c}\boldsymbol{G}_{\mathbf{0}} \\
(\mathbf{M P a})\end{array}$ & \multicolumn{1}{c}{$\boldsymbol{g}_{\mathbf{1}}$} & $\boldsymbol{\tau} \mathbf{1}$ & $\boldsymbol{g}_{\mathbf{2}}$ & $\boldsymbol{\tau}_{\mathbf{2}}$ & $\boldsymbol{k}_{\text {creep-90 }}$ \\
\hline Compression & $20 \%$ & 2898 & 1182 & 0.100 & 0.080 & 0.188 & 12.129 & 0.40 \\
Creep Test & $30 \%$ & 2898 & 1182 & 0.121 & 0.167 & 0.159 & 7.585 & 0.41 \\
& $40 \%$ & 2898 & 1182 & 0.085 & 0.447 & 0.145 & 13.490 & 0.30 \\
\hline Tension & $20 \%$ & 7256 & 2961 & 0.108 & 0.048 & 0.201 & 14.705 & 0.44 \\
Creep Test & $30 \%$ & 7256 & 2961 & 0.089 & 0.092 & 0.230 & 15.903 & 0.46 \\
& $40 \%$ & 7256 & 2961 & 0.078 & 0.851 & 0.215 & 28.192 & 0.39 \\
\hline
\end{tabular}

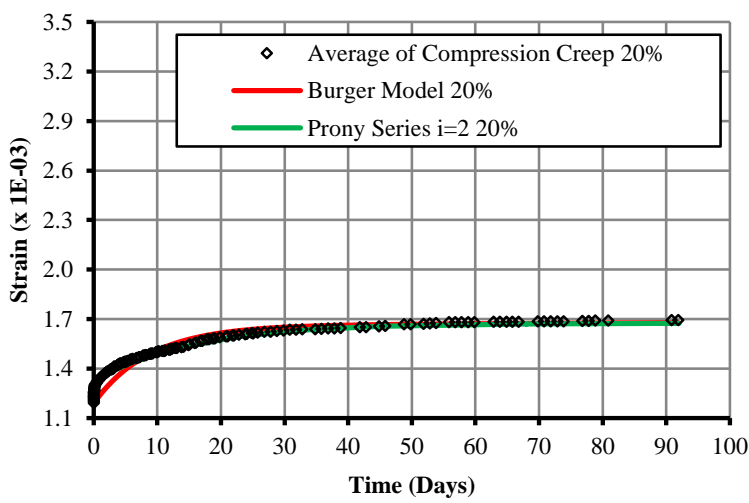

(a)

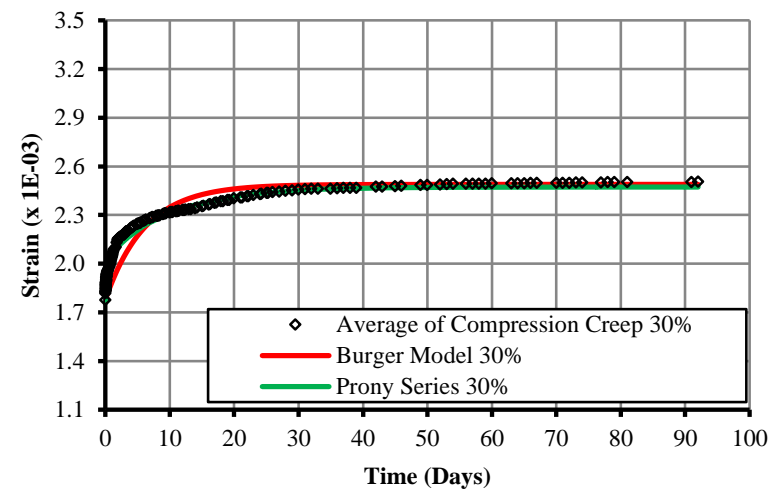

(b)

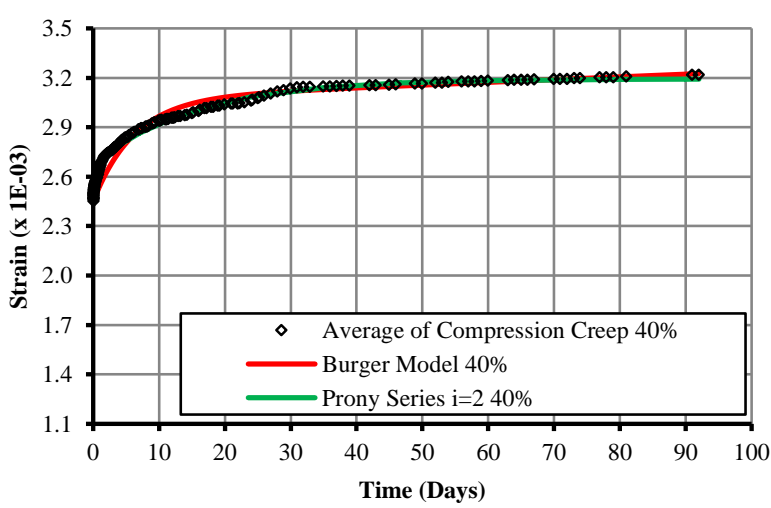

(c)

Figure 11. Curve fitting of Burger and Prony series models of the compression creep for load levels a) $20 \%$, b) $30 \%$, and c) $40 \%$ 


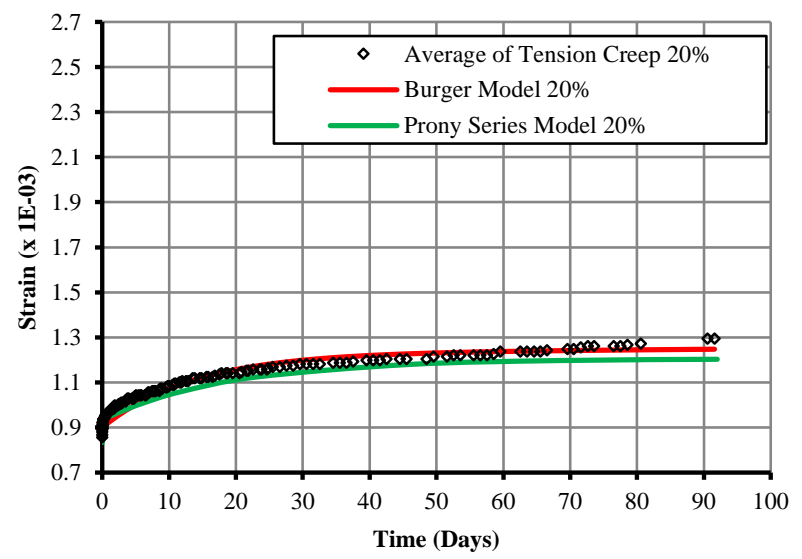

(a)

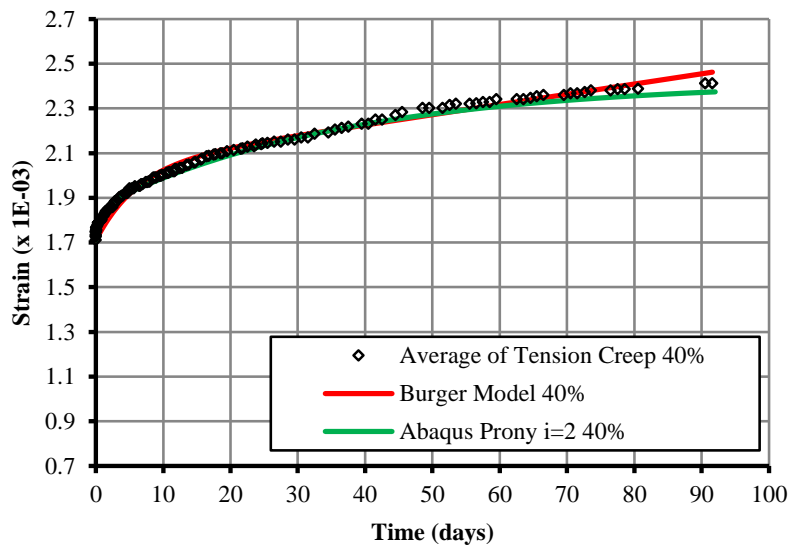

(b)

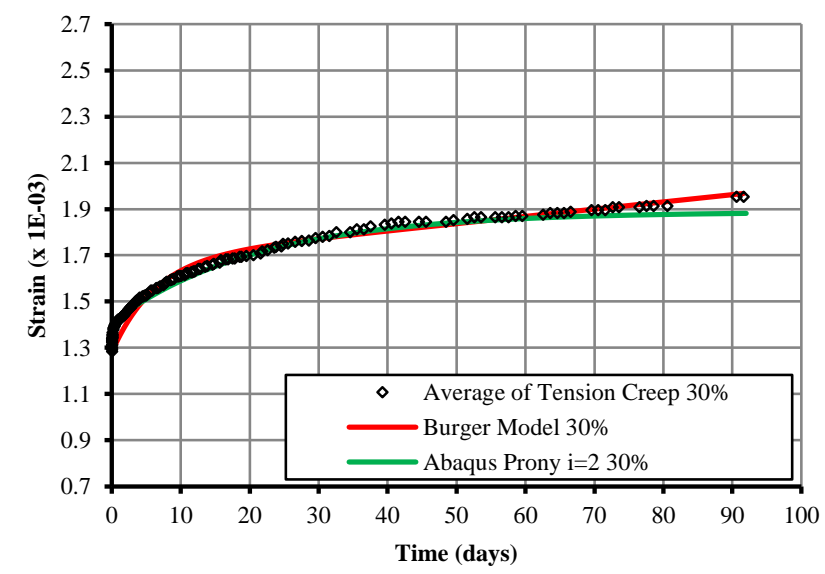

(c)

Figure 12. Curve fitting of Burger and Prony series models of the tension creep for load level: a) $20 \%$, b) $30 \%$, and c) $40 \%$

Figures 11 and 12 show the curve fitting of the creep test result using the Burger and Prony series $(i=2)$ models. The curve fitting of compression and tension creep test data was conducted using the Burger and the Prony series $(i=2)$ models and the relative creep of LVL Sengon in compression was presented in Figure 13.a and the tension in Figure 13.b. According to Equation (1), the relative creep value or creep factor, $k_{\text {creep }}$, is a function of initial strain in all the three levels of the load as observed, is $0.42,0.41$, and 0.31 for relative compression strain creep and is $0.51,0.51$, and 0.41 for the tension for $20 \%, 30 \%$, and $40 \%$ load levels, respectively. The creep factors for 90 days $\left(k_{\text {creep- }} 90\right)$ from Burger and Prony series model are summarized in Tables 3 and 4, respectively and they were both able to predict the long-term creep and also determine the relative creep or creep factor.

The creep factor at $40 \%$ for compression and tension creep was found to be smaller than $20 \%$ and $30 \%$ and this is contrary to the theory of wood and wood-based materials creep. Morlier [29] and Dinwoodie [30] stated wood and wood-based panels exhibit linear viscoelastic behavior on creep testing and have the same or linearly increased creep factor value under $45 \%$ to $60 \%$ stress levels. However, some data on relative creep of stress level at $45 \%$ were less than $30 \%$. The result of the creep tests conducted by Gunawan [31] and 
Kullit [32] on a small specimen simple beam and cantilever of the LVL Sengon, respectively, in a room with controlled temperature, showed creep factor values increased with the load level. However, another research conducted by Gunawan in an uncontrolled temperature showed a decrease when the stress level was increased. Erlitasari [33] and Awaludin, et al. [24] also studied Walikukun wood (Schouthenia ovata Korth) and the same trend was reported.

The parameters of the Burger and Prony series $(i=2)$ models from 90 days creep test was applied to predict the creep factor value of 25 years structural service life and the values for compression were found to be $1.88,0.91$, and 6.40 while for tension was 2.44 , 22.31 , and 24.64 for $20 \%, 30 \%$, and $40 \%$ load levels respectively using the Burger model. These high values are reasonable considering the rising time function in the third part of the Burger equation. Meanwhile, the Prony series $(i=2)$ model for the $20 \%, 30 \%$, and $40 \%$ load level were $0.41,0.70$, and 0.30 for the compression and $0.45,0.46$, and 0.41 for the tension respectively. The values from the compression and tension creep tests were below the 1.5 recommended in SNI 7973: 2013 on the Design Specification for Wood Construction, therefore, it is possible to use the creep factor value in the regulations for design.

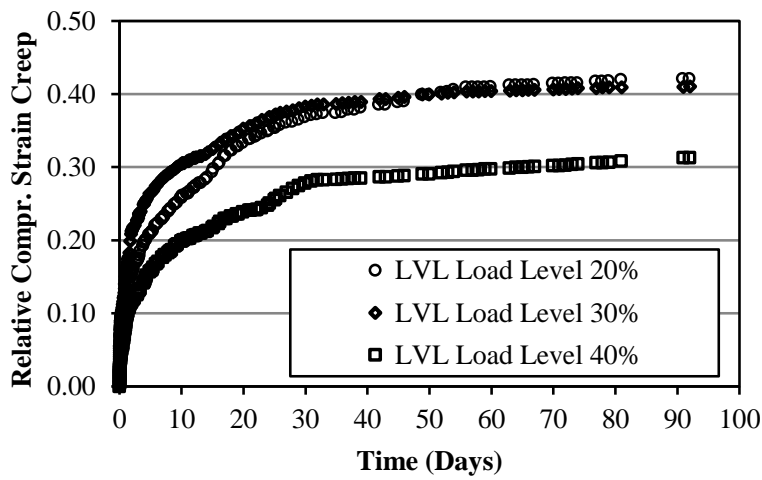

(a)

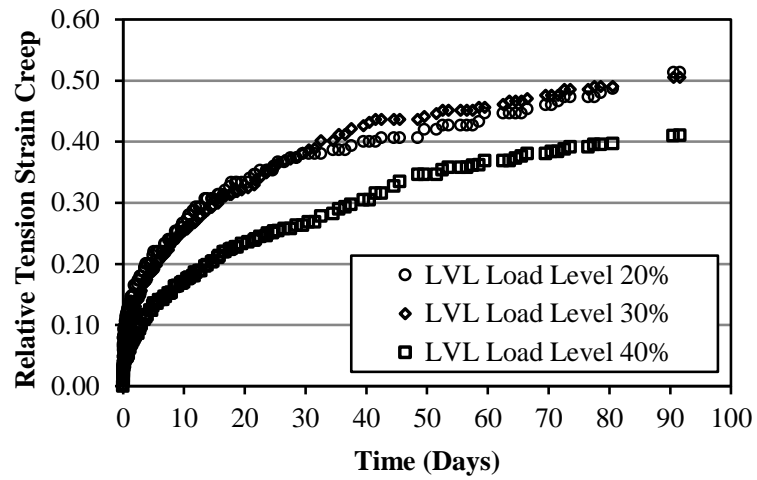

(b)

Figure 13. The average relative strain creep of LVL Sengon, a) compression creep, b) tension creep

The limit of primary and secondary creep stages was calculated based on the Burger model as shown graphically in Figure 2. The compression creeps with load level of $20 \%, 30 \%$, and $40 \%$ were 41,30 , and 44 days while the tension creep were 40,27 , and 26 days respectively. The creep rates of compression were $0.000054,0.000115$, and 0.000103 $\mathrm{mm} / \mathrm{mm} /$ day while the tension had $0.000024,0.000068$, and $0.000059 \mathrm{~mm} / \mathrm{mm} /$ day for the load level of $20 \%, 30 \%$, and $40 \%$, respectively. These values are in line with the findings of Soltis [34] that the creep rate for tension is lower than for the compression.

\section{Conclusions}

There was a variation in the long-term creep behavior of LVL Sengon under compression and tension stresses and the changes in the relative humidity did not significantly influence the deformation of specimens in the creep test room. The creep deformation increased with the load level while the creep factor at $40 \%$ was found to have reduced compared to $20 \%$ and $30 \%$. The creep rate of tension specimens was smaller than that of the compression specimens. Based on the 90 days of testing the compression and tension creep, the Prony series $(i=2)$ model was found to be more suitable to predict 25-years creep factor compared to the Burger model and the value was below the creep factor value suggested in the regulation of design specifications for wood construction in Indonesia (SNI 7973: 2013). 


\section{Acknowledgments}

This research was supported by the Ministry of Research, Technology, and Higher Education, Republic of Indonesia, and Universitas Gadjah Mada through the Penelitian Terapan Unggulan Perguruan Tinggi (PTUPT/2018-2020) research grant. The authors also appreciate the PT. Sumber Graha Sejahtera, Tangerang, for providing LVL Sengon material and assembling LVL Sengon open web truss joist (OWTJ).

\section{References}

[1] I.F. Hanum and L.J.G. van der Maesen, Plant Resources of South-East Asia: No.11 Auxiliary Plant, Backhuys Publisher, Leiden, 1997.

[2] A. Awaludin, Penelitian Sifat-sifat Fisika dan Mekanika Kayu Glugu dan Sengon Kawasan Merapi, Departemen Teknik Sipil dan Lingkungan, Universitas Gadjah Mada, Yogyakarta, Indonesia, 2011. (in Bahasa)

[3] B. Xue and Y. Hu, "Analysis of the microstructure and mechanical properties of laminated veneer lumber,” BioResources, Vol. 8, No. 2, pp. 2681-2695, 2013.

[4] B. Ozarska, "A review of the utilisation of hardwoods for LVL," Wood and Science Technology, Vol. 33, No. 4, pp. 341-351, September 1999.

[5] H. Ido, H. Nagao, H. Kato, A. Miyatake, and Y. Hiramitsu, "Strength properties of laminated veneer lumber in compression perpendicular to its grain," Journal of Wood Science, Vol. 56, pp. 422-428, 2010.

[6] A. Awaludin, S. Shahidan, A. Basuki, S.S. M. Zuki, and F.M. Nazri, "Laminated veneer lumber (LVL) Sengon: An innovative sustainable building material in Indonesia," International Journal of Integrated Engineering, Vol. 10, No. 1, pp. 17-22, 2018.

[7] Y.H. Chui, M.H. Scheider, and H.J. Zhang, "Effects of resin impregnation and process parameters on some properties of Poplar LVL," Forest Product Journal, Vol. 44, pp. 74-78, 1994.

[8] M. Gaff and M. Gasparik, "Influence of densification on bending strength of laminated Beech wood," Bio Resources, Vol. 10, No. 1, pp. 1506-1518, 2015.

[9] B.C. Bal, "Flexural properties, bonding performance and splitting strength of LVL reinforced with woven glass fiber," Construction and Building Material, Vol. 51, pp. 9-15, 2014.

[10] B.C. Bal, "Some technological properties of laminated veneer lumber produced with fast-growing Poplar and Eucalyptus," Maderas Ciencia y Tecnologia, Vol. 18, No. 3, pp. 413-424, 2016.

[11] H. Fu, M. Dun, H. Wang, W. Wang, R. Ou, Y. Wang, T. Liu, and Q. Wang, "Creep response of wood flour-high-density polyethylene/laminated veneer lumber coextruded composites," Construction and Building Material, Vol. 237, p. 117499, 2020.

[12] U. Wusqo, A. Awaludin, A.F. Setiawan, and I.S. Irawati, "Study of laminated veneer lumber (LVL) Sengon to concrete joint using two-dimensional numerical simulation," Journal of the Civil Engineering Forum, Vol. 5, No. 3, p. 275, 2019.

[13] M. Hadi, R. Setiadji, A. Firmanti, B. Subiyanto, and K. Komatsu, "Performance of composite shear wall panel of LVL and GRC board," In: World Conference on Timber Engineering, Aukland, New Zealand, 2012.

[14] C. Bengtsson, "Mechano-sorptive bending creep of timber - influence of material parameters," Holz als Roh- und Werkstoff, Vol. 59, pp. 229-236, 2001.

[15] Y. Shen and R. Gupta, "Evaluation of creep behavior of structural lumber in a natural environment," Forest Product Journal, Vol. 47, No. 1, pp. 89-96, 1997. 
[16] H. Epmeier, M. Johansson, R. Kliger, and M. Westin, "Bending creep performance of modified timber," Holz Roh Werkst, Vol. 65, pp. 343-351, 2007.

[17] G. Granello and A. Palermo, "Creep in timber: Research overview and comparison between code provisions," New Zealand Timber Design Journal, Vol. 27, No. 1, pp. 6$22,2019$.

[18] American Forest and Paper Association, National Design Specification for Wood Construction, Washington D.C., United States, 2000.

[19] Badan Standarisasi Nasional, SNI 7973:2013 Spesifikasi Desain untuk Konstruksi Kayu (Design Spesification for Wood Construction), Jakarta, Indonesia, 2013. (in Bahasa)

[20] J. Bodig and B.A. Jayne, Mechanics of Wood and Wood Composites, Reprint Edition 1993 ed., Krieger Publishing Company, Malabar, Florida, United States, 1982.

[21] F. Daver, M. Kajtaz, M. Brandt and R.A. Shanks, "Creep and recovery behaviour of polyolefin-rubber nanocomposites developed for additive manufacturing," Polymers, Vol. 8, No. 437, pp. 1-13, 2016.

[22] J.B. Wang, R.O. Foschi and F. Lam, "Duration of load and creep effects in strand-based wood composite: A crerp-rupture model," Wood Science Technology, Vol. 46, pp. 375391, 2012.

[23] E.J. Barbero, Finite Element Analysis of Composite Materials Using Abaqus, CRC Press, Boca Raton, 2013.

[24] A. Awaludin, Ngudiyono, and A. Basuki, "Creep properties of Walikukun (Schouthenia ovata) timber beams," Civil Engineering Dimension, Vol.18, No.2, vol. 18, no. 2, pp. 78-84, September 2016.

[25] S.C. Bloch, EXCEL for Engineers and Scientists, John Wiley \& Sons, Inc., Florida, United States, 2007.

[26] ASTM (American Society for Testing and Material), ASTM D 143 Standard Test Methods for Small Clear Specimens of Timber, 2006.

[27] C. Niken, E. Tjahjono, and F.X. Supartono, "The influence of water content for longterm shrinkage of concrete under humid tropical climate," In: The 6th Civil Engineering Conference in Asia Region: Embracing the Future through, Jakarta, Indonesia, 2013.

[28] I.G.L.B. Eratodi and A. Awaludin, "Bending capacity of non-prismatic LVL beams Paraserianthes falcataria," Procedia Engineering, Vol. 171, pp. 1362-1369, 2017.

[29] P. Morlier, ed., RILEM Report 8: Creep in Timber Structure, Taylor \& Francis eLibrary, London, United Kingdom, 2005.

[30] J.M. Dinwoodie, Timber: Its Nature and Behaviour, E \& FN SPON, New York, 2004.

[31] J.M. Gunawan, Perilaku Rangkak (Creep) Balok LVL Kayu Sengon (Parserianthes falcataria) Tumpuan Sederhana, Unpublished Master Thesis, Departemen Teknik Sipil dan Lingkungan, Yogyakarta, Indonesia, 2013. (in Bahasa)

[32] R.A. Kullit, Perilaku Creep Balok Laminated Veneer Lumber Kayu Sengon (Paraserianthes falcataria) dengan Tumpuan Kantilever, Unpublished Master Thesis, Departemen Teknik Sipil dan Lingkungan, Yogyakarta, Indonesia, 2013. (in Bahasa)

[33] E. Erlitasari, The Creep Behaviour of Walikukun Wood (Schouthenia ovata Korth) (in Bahasa), Unpublished Master Thesis, Departemen Teknik Sipil dan Lingkungan, Yogyakarta, Indonesia, 2013.

[34] L.A. Soltis, W. Nelson, and J.L. Hillis, "Creep of structural lumber," In: Proceeding 3d Joint ASCE/ASME Mechanics Conference: Mechanics of Cellulosic and Polymeric Materials, San Diego, New York, 1989. 